\title{
Seasonal variation of soluble carbohydrates and starch in Echinolaena inflexa, a native grass species from the Brazilian savanna, and in the invasive grass Melinis minutiflora
}

\author{
Souza, A. ${ }^{\mathrm{a}, \mathrm{b}}$, Sandrin, CZ. ${ }^{\mathrm{a}, \mathrm{b}}$, Calió, MFA. ${ }^{\mathrm{b}}$, Meirelles, ST. ${ }^{\mathrm{b}}$, \\ Pivello, VR. ${ }^{\mathrm{b}}$ and Figueiredo-Ribeiro, RCL. ${ }^{\mathrm{a} *}$ \\ aSeção de Fisiologia e Bioquímica, Instituto de Botânica, \\ Av. Miguel Estéfano, 3687, CP 3005, CEP 01061-970, São Paulo, SP, Brazil \\ 'Instituto de Biociências, Universidade de São Paulo - USP, \\ Rua do Matão, Trav. 14, 321, Cidade Universitária, CEP 05508-090, São Paulo, SP, Brazil \\ *e-mail: ritarib@usp.br \\ Received November 11, 2008 - Accepted May 14, 2009 - Distributed May 31, 2010
}

(With 8 figures)

\begin{abstract}
Echinolaena inflexa (Poir.) Chase is an abundant C3 grass species with high biomass production in the Brazilian savanna (cerrado); Melinis minutiflora Beauv. is an African C4 forage grass widespread in cerrado and probably displacing some native herbaceous species. In the present work, we analysed seasonally the content and composition of soluble carbohydrates, the starch amounts and the above-ground biomass (phytomass) of E. inflexa and M. minutiflora plants harvested in two transects at 5 and $130 \mathrm{~m}$ from the border in a restrict area of cerrado at the Biological Reserve and Experimental Station of Mogi-Guaçu (SP, Brazil). Results showed that water soluble carbohydrates and starch amounts from the shoots of both species varied according to the time of the year, whilst in the underground organs, variations were observed mainly in relation to the transects. Marked differences in the pattern of the above-ground biomass production between these two grasses relative to their location in the Reserve were also observed, with two peaks of the invasive species (July and January) at the Reserve border. The differences in carbohydrate accumulation, partitioning and composition of individual sugars concerning time of the year and location in the Reserve were more related to the annual growth cycle of both grasses and possibly to specific physiological responses of M. minutiflora to disturbed environments in the Reserve border.
\end{abstract}

Keywords: biological invasion, cerrado, starch, sugars, tropical grasses.

\section{Variações sazonais de carboidratos solúveis e amido em Echinolaena inflexa, uma espécie nativa do cerrado, e na gramínea invasora Melinis minutiflora}

\section{Resumo}

Echinolaena inflexa (Poir.) Chase é uma gramínea C3 muito abundante em áreas de cerrado e com alta produção de biomassa. Melinis minutiflora Beauv. é uma gramínea C4 de origem africana introduzida no Brasil para fins forrageiros, que se espalhou amplamente por áreas de cerrado, provavelmente deslocando espécies nativas. No presente trabalho, o conteúdo e a composição de carboidratos solúveis, o teor de amido e a biomassa aérea foram analisados sazonalmente em plantas de E. inflexa e M. minutiflora coletadas em dois transectos, a 5 e $130 \mathrm{~m}$ da borda da Reserva Biológica e Estação Experimental de Mogi-Guaçu, uma área restrita de cerrado (SP, Brasil). Os resultados mostraram que os carboidratos solúveis e o conteúdo de amido da parte aérea de ambas as espécies variaram de acordo com a época do ano, enquanto que nos órgãos subterrâneos as variações foram observadas principalmente em relação aos transectos. Diferenças marcantes no padrão de distribuição de biomassa aérea das duas espécies em relação à localização na reserva também foram observadas, com dois picos de produção da espécie invasora (em julho e janeiro) na borda da reserva. As diferenças observadas no acúmulo de carboidratos, partição e composição dos açúcares em relação à época do ano e localização na reserva foram mais relacionadas ao ciclo anual de crescimento de ambas as espécies e possivelmente a respostas fisiológicas específicas de $M$. minutiflora a ambientes perturbados na borda da reserva.

Palavras-chave: invasão biológica, cerrado, amido, açúcares, gramíneas tropicais. 


\section{Introduction}

Biological invasion is a serious threat to the biodiversity of natural ecosystems (Vitousek, 1990). Invasion by alien grasses has been shown to modify the physiognomy and structure of neotropical savannas, not only by excluding native species, but also increasing fire frequency and intensity, thereby modifying the ecosystem as a whole (Humphrey and Schupp, 2004; D'Antonio and Vitousek, 1992; Hoffman et al., 2004; Pivello et al., 1999a). Perennial African C4 grasses are very successful invaders in savanna areas, as they have traits that give them a strong competitive advantage compared to the native species, such as tolerance to grazing, fire and low soil nutrient availability (D'Antonio and Vitousek, 1992; Williams and Baruch, 2000; Rosas et al., 2006).

In Brazil, several exotic grass species were introduced as cattle forage and spread widely in open areas of a savanna-like vegetation (cerrado). Among them is the perennial Melinis minutiflora Beauv. (Molasses grass), which is native to Africa but nowadays is widespread throughout the tropics (Baruch and Gomez, 1996; D'Antonio and Vitousek, 1992; Hoffmann et al., 2004). This species, as well as other African grasses, holds several traits such as high seed production, efficient vegetative growth and investment in shoot production (Filgueiras, 1990; Klink and Joly, 1989; Simões and Baruch, 1991) that allow them to form dense mats that exclude many other herbaceous native species (Pivello et al., 1999b). Additionally, C4 photosynthetic pathway frequently found in African species may increase their efficiency over the $\mathrm{C} 3$ native grasses in occupying open and sunny environments (Klink and Joly, 1989).

Despite the ability of $M$. minutiflora to outcompete native grasses, Pivello et al. (1999a) observed that in the Emas Biological Reserve (SP) the native $\mathrm{C} 3$ grass Echinolaena inflexa (Poir.) Chase showed phytosociological patterns (absolute density, frequency, vigor) and distribution very similar to those observed in $M$. minutiflora. High values of above-ground biomass and density of both species indicated that the invasive grass was not displacing the native one. The great ability of both species to produce biomass and to grow vegetatively could explain their high density (Klink, 1996; Filgueiras, 2002), which could be directly related to photosynthetic rate and carbohydrate partitioning. As shown for temperate forage grasses, the accumulation of non-structural carbohydrates (NSC) has been considered an efficient strategy to allow growth and survival in periods when photosynthesis becomes reduced (Kingston-Smith et al., 1998).

In spite of differences concerning origin and photosynthetic metabolism, previous studies showed similar composition of individual sugars in vegetative tissues of M. minutiflora and E. inflexa (Moraes et al., 2002) and suggested they have similar metabolic strategies to overcome the stressing conditions of the cerrado. The diurnal pattern of NSC in both species (Souza et al., 2005) was at- tributed to possible differences of starch metabolism, the main carbon reserve of tropical grasses (Chatterton et al., 1989). Furthermore, although previous studies demonstrated co-existence of E. inflexa and $M$. minutiflora in different cerrado fragments, the invasive species seems to be present in higher density in border areas, which could also be related with particularities concerning carbohydrate metabolism.

Therefore, in the present work, we investigate the contents of water soluble carbohydrate and starch in vegetative organs of $M$. minutiflora and E. inflexa harvested from two transects in a restrict cerrado fragment, representing the border and the internal parts of this site, aiming at to correlate carbohydrate accumulation, phytomass production and the distribution of both species in the cerrado.

\section{Material and Methods}

\subsection{Plant material and study area}

Vegetative tissues (leaves and culms) and underground organs of $M$. minutiflora and E. inflexa were harvested from plants growing in a Brazilian savanna area located in the Biological Reserve of Mogi-Guaçu $\left(22^{\circ} 15^{\prime}-22^{\circ} 16^{\prime} \mathrm{S}\right.$ and $47^{\circ} 08^{\prime}-47^{\circ} 12^{\prime} \mathrm{W}$, Mogi-Guaçu, SP, Brazil) in April, July and October/2001 and January/2002. Plants were harvested in two transects, each $300 \mathrm{~m}$ long, one at $5 \mathrm{~m}$ (named external transect ExT) and the other at $130 \mathrm{~m}$ (named internal transect InT) from the Reserve border. Along each transect, $1 \times 1 \mathrm{~m}^{2}$ plots were randomly selected and plant material for carbohydrate analysis was collected from 6 plots. Above-ground material was also randomly harvested in 10 other plots and measured for total biomass (phytomass) determination at each harvesting time.

\subsection{Extraction and analyses of Water Soluble Carbohydrates (WSC)}

After harvesting, underground organs (roots for $M$. minutiflora and roots and rhizomes for E. inflexa) and aerial vegetative tissues (excluding reproductive structures) were separated. Fresh weight $(\mathrm{FW})$ of each tissue fraction was determined in the field and coarsely chopped. Each fraction from individual plants was thoroughly mixed, and three sub-samples were taken for carbohydrate analyses. WSC was extracted from fresh tissues in boiling $80 \%$ ethanol followed by hot water (Pollock and Jones, 1979). The aqueous and ethanolic extracts were pooled and concentrated in a rotary evaporator. Total sugars were determined by the phenol-sulphuric acid procedure (Dubois et al., 1956), using glucose as standard. Aliquots of carbohydrate extracts were deionized using Sep-Pack Accell Plus QMA and CM cartridges, and hydrophobic compounds were removed using Sep-Pack $\mathrm{tC}_{18}$ cartridges. All cartridges were supplied by Waters Chromatography Division of Millipore Co. (USA).

Oligosaccharides were analysed by high performance anion exchange chromatography with pulsed amperomet- 
ric detection (HPAEC-PAD), on a Dionex DX-300, in a CarboPac PA-1 $(4 \times 250 \mathrm{~mm})$, using a linear gradient of sodium acetate in sodium hydroxide $(150 \mathrm{mM})$, according to Itaya et al. (1997). The elution program consisted of a sodium hydroxide gradient $\left(1 \mathrm{~cm}^{3} / \mathrm{min}\right)$ of $12 \mathrm{mM}$ (0-2 minutes), $24 \mathrm{mM}$ (2-5 minutes), $44 \mathrm{mM}$ (5-9 minutes), $54 \mathrm{mM}$ (9-13 minutes), $62 \mathrm{mM}$ (13-16 minutes), $66 \mathrm{mM}$ (16-18), $96 \mathrm{mM}$ (18-25 minutes), $120 \mathrm{mM}$ (25-30), $140 \mathrm{mM}$ (35-40 minutes) and $12 \mathrm{mM}$ (41 minutes). Quantification of individual sugars was performed according to Timmermans et al. (1994), by the external standard method using authentic standards (Sigma).

\subsection{Determination of starch content}

Dried samples of aerial and underground organs were ground to a fine powder in a ball mill for starch analysis and performed according to the method proposed by Arêas and Lajolo (1980), modified as follows: $10 \mathrm{mg}$ of ground material was weighed in Eppendorf tube and submitted to extraction with $80 \%$ ethanol $\left(\mathrm{v} \cdot \mathrm{v}^{-1}\right)$ at $80{ }^{\circ} \mathrm{C}$. After centrifugation at 13,000 g for 5 minutes, the supernatant was discarded. This procedure was repeated twice. The residue was solubilised in $1.5 \mathrm{~mL}$ of $50 \mathrm{mM} 3$-[N-morpholin] propan-sulfonic acid buffer (MOPS), $\mathrm{pH} 7.0$, at $30^{\circ} \mathrm{C}$ for 1 hour. To initiate the digestion, 28 U.mL ${ }^{-1}$ of $\alpha$-amylase (Megazyme) in $50 \mathrm{mM}$ 3-[N-morpholin] propan-sulfonic acid buffer (MOPS), $\mathrm{pH}$ 7.0, were added and the extract was incubated for 1 hour at $70{ }^{\circ} \mathrm{C}$. After incubation, $1 \mathrm{~mL}$ of $300 \mathrm{mM}$ sodium acetate buffer, $\mathrm{pH} 4.8$, was added, and a new incubation was performed with $28 \mathrm{U} . \mathrm{mL}^{-1}$ of amyloglucosidase (Megazyme) in $100 \mathrm{mM}$ sodium acetate buffer, $\mathrm{pH} 4.8$, for 30 minutes at $50{ }^{\circ} \mathrm{C}$. The reaction was stopped by the addition of $10 \% 0.8 \mathrm{M}$ percloric acid. Free glucose content was determined using a glucose oxidase/peroxidase (GOD/POD) "kit" appropriated for Elisa (Centerlab). An aliquot of the mixture was transferred to a tube and $150 \mu \mathrm{L}$ of glucose oxidase was added. After incubation for 15 minutes at $30{ }^{\circ} \mathrm{C}$, free glucose was quantified by spectrophotometry at $490 \mathrm{~nm}$.

\subsection{Statistics}

A Tukey multiple comparison test (with rejection level $>5 \%$ ) was applied on mean values of carbohydrate contents. To examine the patterns of carbohydrate composition changes in space and time the data matrix was explored through a Principal Components Analysis (PCA). The PCA was based on the correlation matrix obtained from the original data matrix of carbohydrate composition and total biomass in each location and time. The original values were standardised by ranging. The PC-ORD version 3.0 package for Windows (McCune and Mefford, 1997) was used for the analysis.

A multivariate linear model analysis was also performed to verify if phytomass variation in plants from both transects could be predicted by the accumulation of carbohydrates. The data were analysed by means of a stepwise method, adopting phytomass as a dependent variable and the accumulation of WSC, starch, glucose, fructose and sucrose as independent variables. The adjustment procedure started from the saturated model (with all the variables present); variables which had lower influence to explain phytomass variation (greatest value of $\mathrm{p}$ ) were successively removed. At each step, the adjustment and the variable significance were evaluated; only those that significantly contributed to explain the variation remained.

\section{Results}

Meteorological data for the period of this study were sourced from a weather station located at the Biological Reserve. Monthly mean values of maximum, medium and minimum temperatures and total precipitation, relative air humidity and total radiation are shown in Figure 1. Precipitation was low (less than $80 \mathrm{~mm}$ ) from April to August/2001, with the lowest value in June (5.5 mm) and high in March, November and December (Figure 1a). Temperature decreased from March to July/2001, with a minimum value of $7.5^{\circ} \mathrm{C}$ in July. Temperatures started to increase in August and the highest mean values were recorded in January/2002 (Figure 1a). The lowest values of total radiation occurred from May to September/2001, and the highest ones from October/2001 to January/2002 (Figure 1b). Monthly fluctuations in the meteorological
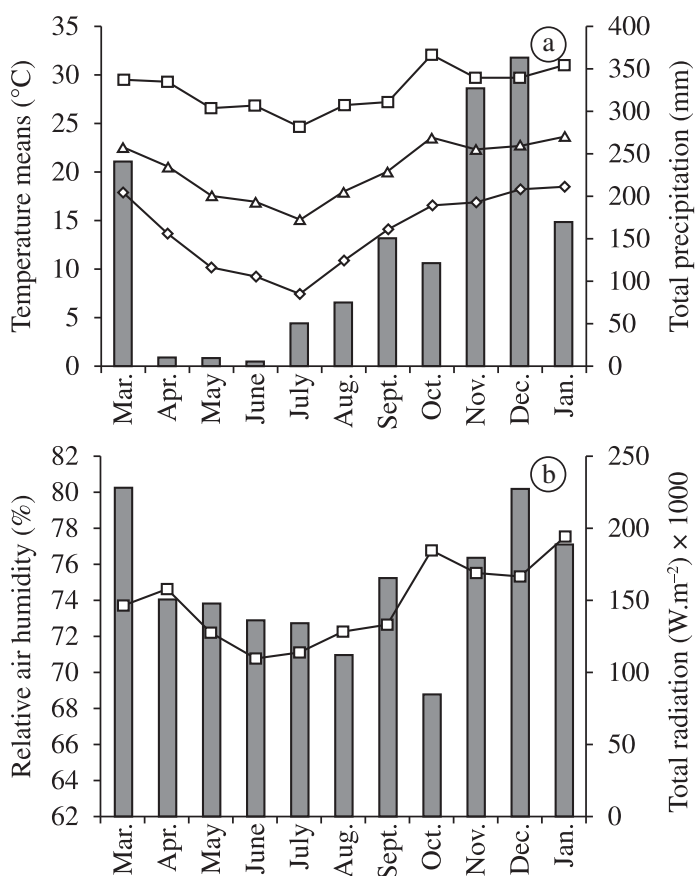

Figure 1. Meteorological data of the Mogi-Guaçu Biological Reserve (SP, Brazil) during the study period (March/2001 to January/2002). a) monthly average values for maximum $(\square)$, mean $(\Delta)$ and minimum $(\diamond)$ temperature and total precipitation (bars); b) relative air humidity (bars) and total radiation ( $\square)$. 
data are typical for a subtropical region, with low levels of precipitation and radiation in April, May, June and July (part of autumn and winter seasons), and high values in November, December and January (part of spring and summer seasons).

Therefore, carbohydrate data evaluated in April and July, corresponded to the driest period, and in October and January, corresponded to wet seasons in this region. Water soluble carbohydrate (WSC) contents in the aerial tissues of E. inflexa and M. minutiflora harvested in the internal (InT) and external (ExT) transects showed not to be significantly affected by the location in the Biological Reserve (Table 1). However, significant differences were observed among the analysed periods (Figure 2). In the native grass higher values were found in July, while in the invasive species $M$. minutiflora the highest WSC content was observed in April, followed by a decline in July.

With respect to the underground organs, both species showed high levels of WSC in July (Figure 3), except $M$. minutiflora in the internal transect, presenting the highest WSC content in April, similarly to what was observed for the shoots (Figure 2).

The main components of the WSC fraction in the shoots of both species were glucose, fructose and sucrose.

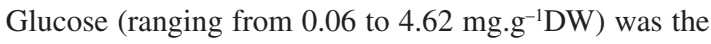
major sugar in the shoots of E. inflexa and M. minutiflora in the four analysed periods, followed by fructose (ranging from 0.01 to $1.55 \mathrm{mg} . \mathrm{g}^{-1} \mathrm{DW}$ ) and sucrose (ranging from 0.04 to $1.31 \mathrm{mg} . \mathrm{g}^{-1} \mathrm{DW}$ ) - (Figure 4). In spite of the great variation observed in the concentrations of all these sugars in aerial tissues of both species, it seemed to be less affected by the location in the Reserve in the native species E. inflexa (Figure 4a, C, E). In contrast, glucose concentration in the alien $M$. minutiflora was significantly different in both transects, especially in July and October (Figure 4b).

In the underground organs of both species sucrose was the main sugar, ranging from 0.33 to $3.33 \mathrm{mg} . \mathrm{g}^{-1} \mathrm{DW}$ in plants from the internal and external transects; the higher sucrose contents were observed in April and July (Figure 5).

Starch was present in much higher amounts than glucose, fructose and sucrose, ranging from 11 to $55 \mathrm{mg} . \mathrm{g}^{-1}$ DW in the shoots of both species during the different analysed periods (Figure 6). In the native grass E. inflexa starch content was higher in the shoots in April

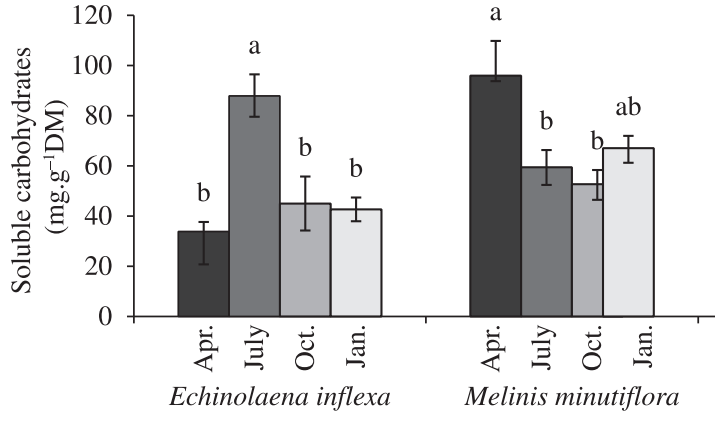

Figure 2. Soluble carbohydrate content (mg.g $\left.{ }^{-1} \mathrm{DM}\right)$ in the shoots of Echinolaena inflexa and Melinis minutiflora plants growing in the Mogi-Guaçu Biological Reserve (SP, Brazil) in April, July, October and January. Values indicated by different letters are significantly different $(\mathrm{P}<0.05)$.
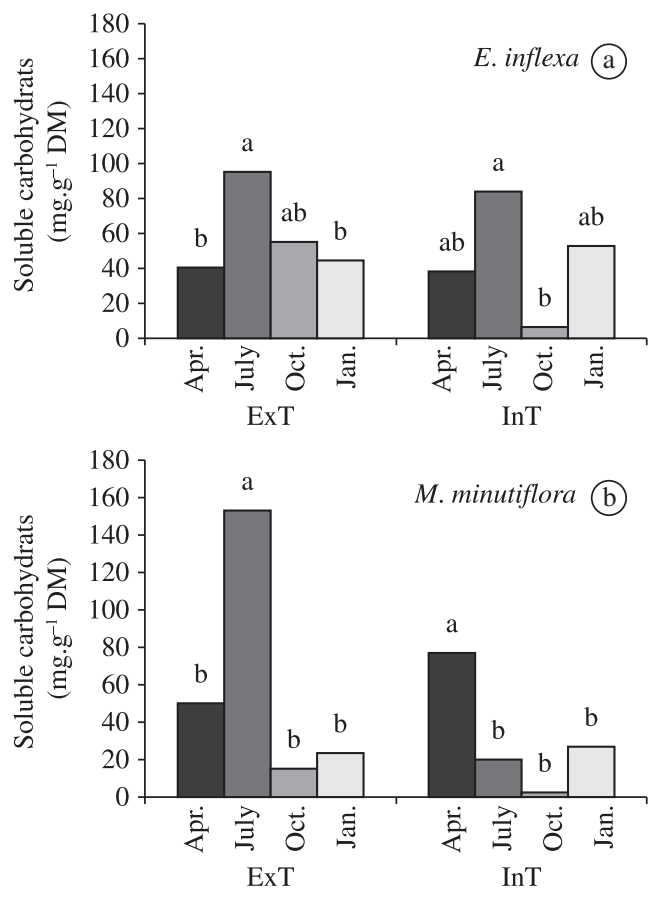

Figure 3. Water soluble carbohydrate content (mg.g $\left.{ }^{-1} \mathrm{DM}\right)$ in the roots of Echinolaena inflexa and Melinis minutiflora harvested in the internal (InT) and external (ExT) transects at Mogi-Guaçu Biological Reserve (SP, Brazil) in April, July, October and January. Values indicated by different letters are significantly different $(\mathrm{P}<0.05)$.

Table 1. Water soluble carbohydrate (WSC) content (mg. $\left.\mathrm{g}^{-1} \mathrm{DM}\right)$ in the shoots of Echinolaena inflexa and Melinis minutiflora growing in Mogi-Guaçu Biological Reserve (SP, Brazil) during the seasons of the year. ExT - external transect; InT internal transect. Data are expressed as mean \pm SE $(n=6)$. Letters compare means between transects for each species. Values followed by the same letter do not differ significantly $(\mathrm{P}<0.05)$.

\begin{tabular}{lccccc}
\hline & & \multicolumn{4}{c}{ WSC (mg.9 $\left.\mathbf{-}^{-1} \mathbf{D M}\right)$} \\
\cline { 3 - 6 } & & April & July & October & January \\
\hline \multirow{2}{*}{ E. inflexa } & Ext & $74.9 \pm 6.3^{\mathrm{a}}$ & $84.0 \pm 13.9^{\mathrm{a}}$ & $54.8 \pm 20.1^{\mathrm{a}}$ & $33.8 \pm 7.1^{\mathrm{a}}$ \\
& InT & $37.8 \pm 5.2^{\mathrm{a}}$ & $91.7 \pm 8.3^{\mathrm{a}}$ & $34.9 \pm 6.9^{\mathrm{a}}$ & $51.4 \pm 3.6^{\mathrm{a}}$ \\
& Ext minutiflora & $29.0 \pm 9.8^{\mathrm{a}}$ & $61.9 \pm 13.1^{\mathrm{a}}$ & $53.2 \pm 8.1^{\mathrm{a}}$ & $68.1 \pm 8.0^{\mathrm{a}}$ \\
& InT & $116.2 \pm 24.5^{\mathrm{a}}$ & $56.6 \pm 7.3^{\mathrm{a}}$ & $51.6 \pm 9.7^{\mathrm{a}}$ & $79.9 \pm 7.2^{\mathrm{a}}$ \\
\hline
\end{tabular}



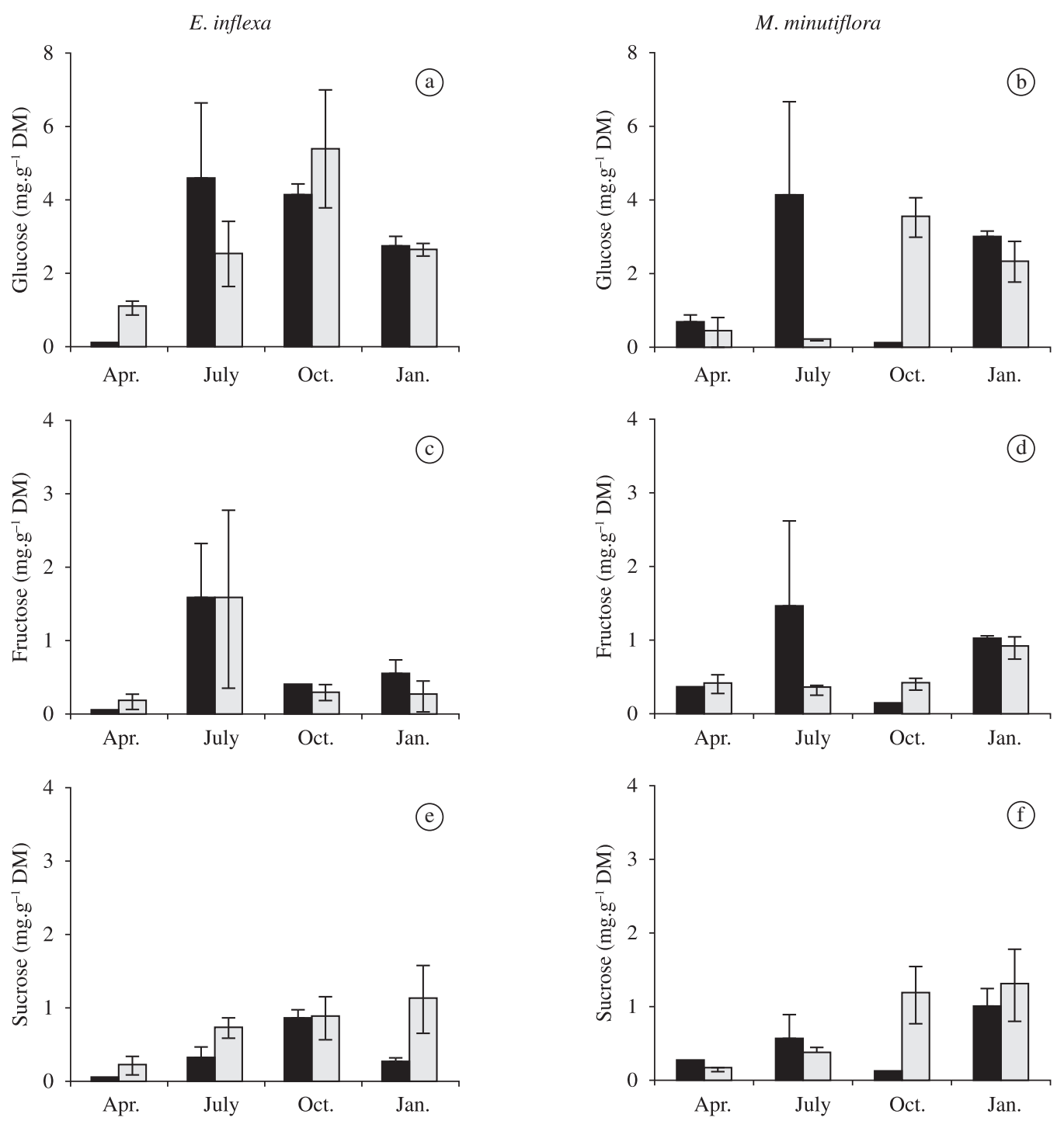

Figure 4. Contents of glucose (a, b), fructose (c, d) and sucrose (e, f) in the shoots of Echinolaena inflexa and Melinis minutiflora harvested in the external (black bars) and internal (gray bars) transects at Mogi-Guaçu Biological Reserve (SP, Brazil). Bars indicate standard error.

and July (Figure 6a), and the distribution pattern was similar in both transects. In M. minutiflora, the pattern of starch variation was similar to that found in E. inflexa in ExT, but in InT higher amounts were observed in October and January (Figure 6b). In general, the starch amounts in the underground organs of both species were lower than those of the shoots throughout the analysed period (Figure 6c, d), except in October for E. inflexa at the internal transect.

Differences in the above-ground production of phytomass by the native and the invasive species were observed in both transects (Figure 7). Near the Reserve border (ExT) (Figure 7a), E. inflexa was not found in July, coinciding with the remarkable phytomass production by M. minutiflora. This last species also presented a peak of phytomass production in January. In the internal transect (InT - Figure 7b), both species were present throughout the analysed period, E. inflexa predominating in April. However, in contrast with ExT, the invasive species $M$. minutiflora did not show peaks of phytomass production in the internal transect.

The pattern of carbohydrate (WSC and starch from shoots and underground organs) concentrations related to species, time and space was explored through the interpolation of the two first axes resulting from the Principal Component Analysis (Figure 8). The two first axes explained $78 \%$ of the data variance corresponding to $58 \%$ and $20 \%$ in the first and in the second axis, respectively. The major contribution to the first component was aerial phytomass $(r=-0.999)$, while precipitation 

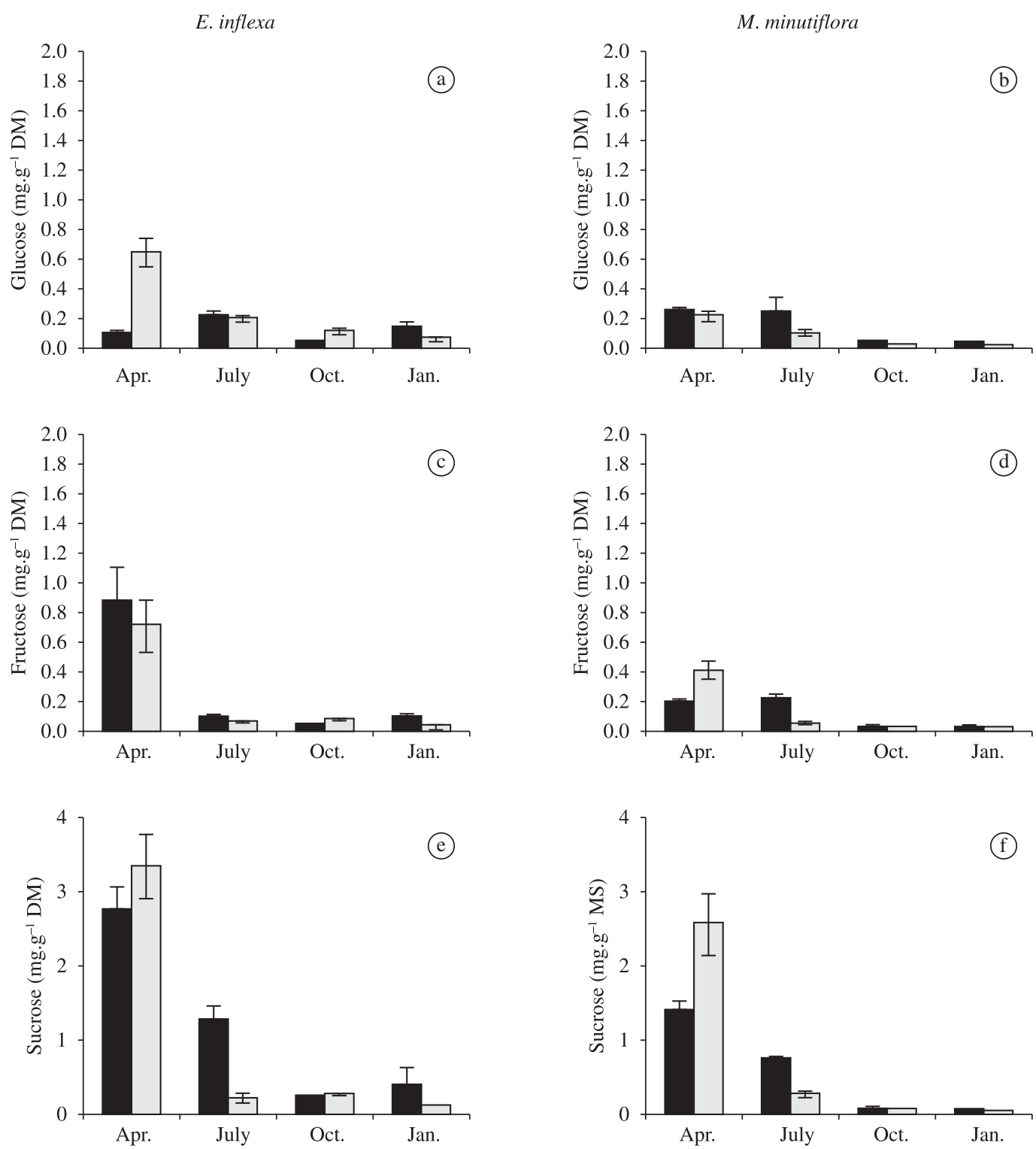

Figure 5. Contents of glucose (a, b), fructose (c, d) and sucrose (e, f) in the roots of Echinolaena inflexa and Melinis minutiflora harvested in the external (black bars) and internal (gray bars) transects at Mogi-Guaçu Biological Reserve (SP, Brazil). Bars indicate standard error.

$(\mathrm{r}=-0.979)$ was the variable that most contributed to the second component (Table 2). Axis 1 seems to reflected a separation between dry (April and July) and wet (October and January) periods, with most of January and October sample units placed at the positive side of the axis, and July and April sample units at the negative side. Sample units of wet months were associated with starch contents and relative air humidity, while sample units of the dry months were related to total WSC, radiation and precipitation levels.

Multivariate stepwise analysis showed that $77 \%$ of the variability in the phytomass production by E. inflexa located in ExT could be significantly pre- dicted by a linear combination of WSC and starch accumulation in shoots (Table 3 ). Results showed that the higher the relative amounts of soluble carbohydrates and starch, the lower was the phytomass. The analysis also showed that $57 \%$ of the variability of E. inflexa phytomass located in the internal transect could be significantly predicted by lower levels of glucose. Analysis involving M. minutiflora showed that $82 \%$ and $63 \%$ of the variability of phytomass production by this species, respectively in ExT and InT, could be significantly predicted by higher contents of glucose and lower contents of fructose. 
E. inflexa
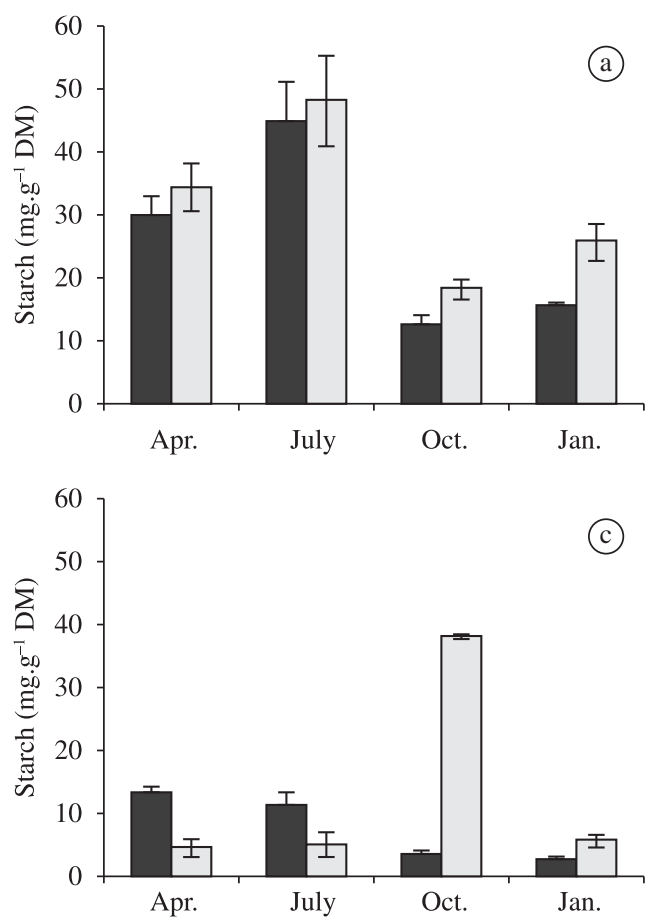

M. minutiflora
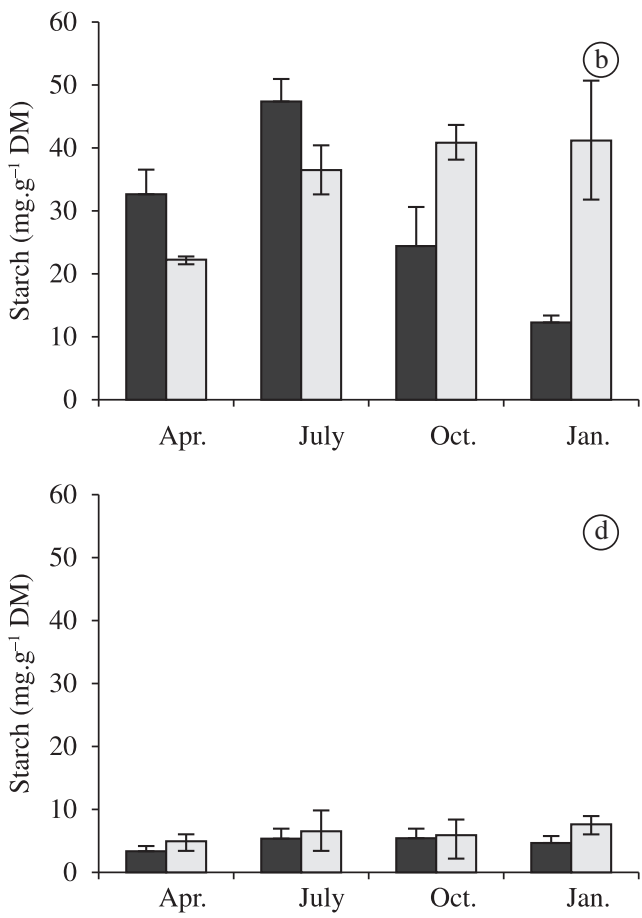

Figure 6. Contents of starch (mg. $\left.\mathrm{g}^{-1} \mathrm{DM}\right)$ in the shoots (a, b) and roots (c, d) of Echinolaena inflexa and Melinis minutiflora harvested in the external (black bars) and internal (gray bars) transects at Mogi-Guaçu Biological Reserve (SP, Brazil) in different periods of the year. Bars indicate standard error.
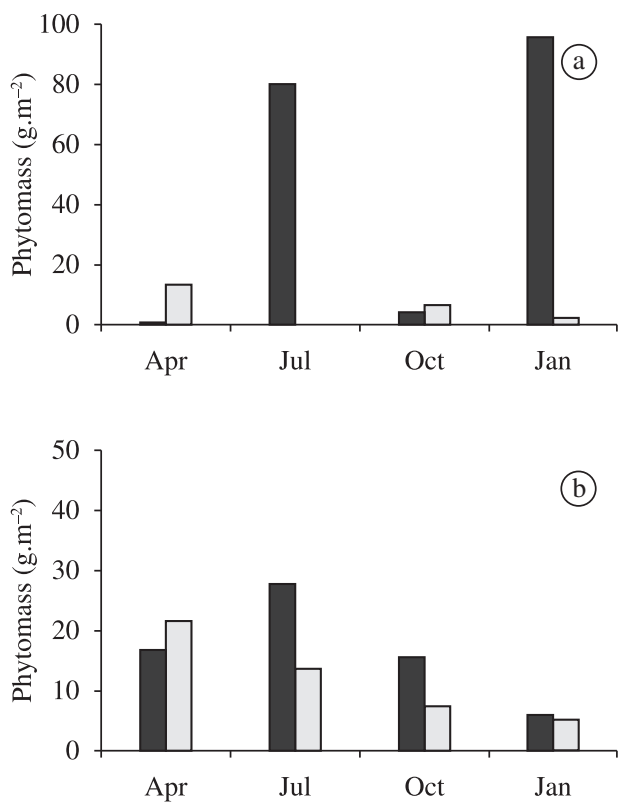

Figure 7. Above-ground phytomass production by Echinolaena inflexa (gray bars) and Melinis minutiflora (dark bars) in the external (a) and internal (b) transects at Mogi-Guaçu Biological Reserve (SP, Brazil) during the study period.
Table 2. Contribution of the six analysed variables to the first and second axes of a principal component analysis (PCA) considering carbohydrate content and phytomass production by Echinolaena inflexa and in two different transects at Mogi-Guaçu Biological Reserve (SP, Brazil). WSC - Water soluble carbohydrates.

\begin{tabular}{lcc}
\hline \multicolumn{1}{c}{ Variables } & \multicolumn{2}{c}{ Principal components } \\
\cline { 2 - 3 } & Axis 1 & Axis 2 \\
\hline Phytomass & -0.370 & 0.111 \\
WSC & -0.390 & -0.525 \\
Starch & -0.474 & $\mathbf{- 0 . 6 9 3}$ \\
Glucose & $\mathbf{- 0 . 7 2 8}$ & 0.506 \\
Fructose & $\mathbf{- 0 . 8 7 1}$ & -0.349 \\
Sucrose & -0.639 & 0.579 \\
Variance explained & $39 \%$ & $26 \%$ \\
\hline
\end{tabular}

\section{Discussion}

The content of the WSC from the shoots of the native $E$. inflexa and the invasive $M$. minutiflora varied significantly according to the period of the year (Figure 2), but was not related with the location at the Biological Reserve, indicating that WSC from the aerial tissues 


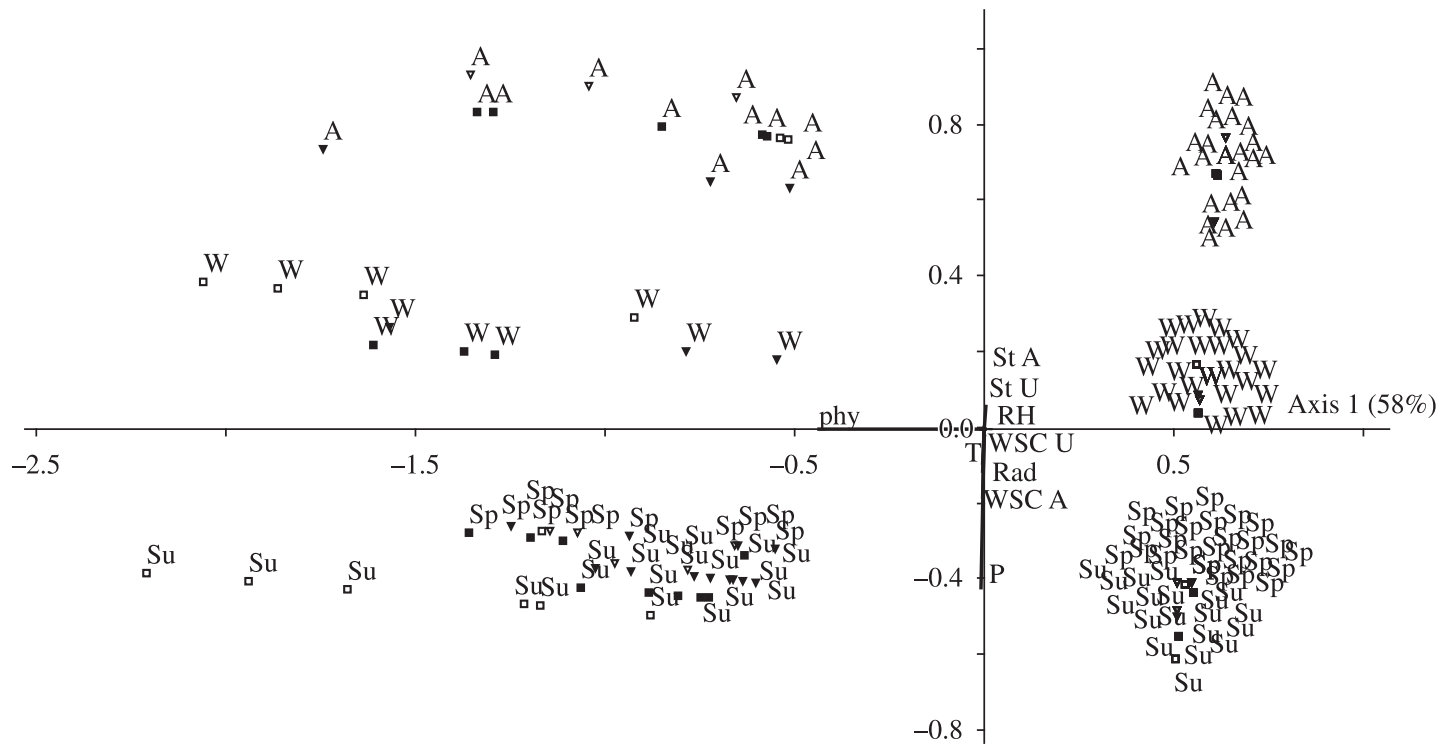

Figure 8. Interpolation of the eigen values obtained for the two first axes resulting from the PCA analysis on the matrix of carbohydrate values of Melinis minutiflora and Echinolaena inflexa in the external and internal transects at Mogi-Guaçu Biological Reserve (SP, Brazil) in April, July, October and January. (open bars) M. minutiflora, ExT; (closed bars) M. minutiflora, InT; (open triangles) E. inflexa, ExT; (closed triangles), E. inflexa, InT. Abbreviations: Phy = phytomass; St A = starch from aerial organs; St U = starch from underground organs; WSC A = water soluble carbohydrates from aerial organs; WSC U = water soluble carbohydrates from underground organs; Rad = radiation; $\mathrm{RH}=$ relative air humidity; $\mathrm{W}=$ winter; $\mathrm{A}=$ autumn; $\mathrm{Sp}=$ spring; $\mathrm{Su}=$ summer.

Table 3. Results from the predictive linear model of phytomass by E. inflexa and M. minutiflora growing in two different transects at Mogi-Guaçu Biological Reserve (SP, Brazil). ExT - external transect; InT - internal transect; WSC - Water soluble carbohydrates from shoots.

\begin{tabular}{cclcc}
\hline Species & Transect & Variables & Coefficient & P \\
\hline E. inflexa $\left(\log _{10}\right)$ & ExT & WSC & -0.02 & 0.015 \\
Constant $=2.79$ & Starch & -0.05 & 0.013 \\
$\mathrm{R}^{2}=0.77(\mathrm{p}=0.001)$ & & & \\
$\mathrm{InT}$ & Glucose & -0.26 & 0.005 \\
Constant $=1.32$ & & & \\
& $\mathrm{R}^{2}=0.57(\mathrm{p}=0.005)$ & & & \\
M. minutiflora $\left(\log _{10}\right)$ & $\mathrm{ExT}$ & Glucose & 1.21 & 0.000 \\
& Constant $=0.66$ & Fructose & -2.62 & 0.001 \\
& $\mathrm{R}^{2}=0.82(\mathrm{p}<0.001)$ & & & \\
& $\mathrm{InT}$ & Glucose & -2.41 & 0.073 \\
& Constant $=33.58$ & Fructose & -15.68 & 0.038 \\
$\mathrm{R}^{2}=0.63(\mathrm{p}=0.012)$ & & & \\
\hline
\end{tabular}

might not be related to phytomass production. Indeed, PCA analysis indicated that both the above-ground phytomass and carbohydrates were more associated with the season (and possibly to their different phenological cycle) than to the location of both species in the Reserve.

Shewmaker et al. (2006) found marked seasonal variations in the concentration of NSC in eight tall fescue (Festuca arundinacea Schreb.) cultivars, being inversely related to dry mass yield. Olson and Wallander (1997), studying the effects of defoliation in other grasses, suggested that the absolute content of NSC alone could not be considered an indicative of aerial biomass production and other factors should contribute to the ability of shoot development, such as the type of carbohydrate accumulated and/or the photoassimilate partitioning. Differences in photoassimilate partitioning have also been found by Kingston-Smith et al. (1998) in 13 grass species, including tropical species such as the starch-accumulating Zea 
mays and the temperate fructan-accumulating Hordeum vulgare. In the present study, differences in the underground reserve organs, carbon partitioning and distinct phenological cycle of $E$. inflexa and $M$. minutiflora (Filgueiras, 2002) could be associated with their above ground production of biomass in the Reserve. The decrease in WSC in the underground organs of M. minutiflora in InT in July was coincident with one of the peaks of phytomass production by this species, suggesting that WSC from the roots could supply energy for its survival in the internal transect of the Reserve, in periods when photosynthesis is limited.

The amounts of the individual sugars of the WSC fraction also differed between underground organs and aerial tissues for both species. In the shoots, the main component was glucose, probably as a result of starch hydrolysis during periods of water restriction and high temperatures. Several studies have demonstrated the role of this sugar in osmotic adjustment under water and heat stresses (Vágújfalvi et al., 1999; Yoshida et al., 1998; Liu and Huang, 2000). In the roots, on the other hand, the most important sugar was sucrose, with higher levels during the dry season for both species, suggesting a storage function, as well as a role in the maintenance of osmotic potential in the underground organs among other functions.

The amount of starch was much higher in shoots than in roots for both species, indicating that the reserve of energy to produce aerial biomass rests in transitory starch, accumulated in leaves during the photosynthetic period. In the native species E. inflexa, the amount of starch varied in the shoots, being lower during rainy periods (January and October) when this species increases vegetative growth, and higher in dry periods (July), which is consistent with a lower investment in vegetative growth. Results showed that the higher the relative concentration of NSC in the aerial tissues, the lower was the phytomass. In contrast, the higher the concentration of glucose (probably as a consequence of starch hydrolysis), more intense was the vegetative growth and phytomass production by $M$. minutiflora in the external transect. Similar behaviour was reported for the tropical grass species Paspalum notatum which showed a reduced growth rate during dry months, followed by a reduction in biomass production, when growing in a subtropical climate (Ribeiro et al., 2006).

The analysis of the phytomass production by the two grasses showed marked differences according to their location in the Reserve. The exotic species M. minutiflora showed high values of phytomass in July and January at the Reserve border (ExT), while the native grass E. inflexa exhibited a comparatively low biomass production in ExT. M. minutiflora may have competitive advantage at the Reserve border thanks to the carbohydrates accumulated in the root system, in addition to the more efficient photosynthetic metabolism characteristic of $\mathrm{C}_{4}$ grasses. According to Leishman et al. (2007), the potential for rapid growth associated with an efficient carbon fixation in open and sunny areas seems to be a key factor of the success of invasive species in environments not resource limited, as the Reserve border can be. Therefore, our data indicate that the border (ExT) is a better habitat for the alien grass at least in July. Indeed, Hoffmann et al. (2004) have already reported the preference of $M$. minutiflora for habitat borders in a cerrado region.

On the other hand, in the inner part of the Reserve (InT) both grasses showed similar phytomass production throughout the year, confirming previous suggestions by Pivello et al. (1999) that the invasive grass M. minutiflora did not displace the native E. inflexa. This might be due to their efficient vegetative propagation and ability to use efficiently their reserves of non-structural carbohydrates (mainly starch) in periods when photosynthesis is reduced. The peaks of phytomass of M. minutiflora in July and January in the Reserve border could be related to its reproductive behaviour, with abundant flowering in July and large shoot growth in the rainy season (January).

In conclusion, the differences in carbohydrate accumulation, partitioning and composition of individual sugars concerning time of the year and location in the Reserve seemed to be more related to the annual growth cycle of both grasses and possibly to specific physiological responses of $M$. minutiflora to disturbed environments in the Reserve border.

Acknowledgements - This study was supported by FAPESP within the BIOTA/FAPESP Program (http://www.biotasp. org.br). The authors thank Dr. Marisa Domingos for helpful suggestions and $\mathrm{CNPq}$ for the technical fellowship to M.P. Monteiro.; A. Souza thanks FAPESP for the Master fellowship, and C.Z. Sandrin thanks The National Research Council for the Development of Science (CNPq) for the PIBIC fellowship. R.C.L. Figueiredo-Ribeiro is a research fellow of CNPq.

\section{References}

ARÊAS, JAG. and LAJOLO, FM., 1980. Determinação enzimática específica de amido, glicose, frutose e sacarose em bananas pré-climatéricas e climatéricas. Anais de Farmácia e Química de São Paulo, vol. 20, no. 1/2, p. 307-318.

BARUCH, Z. and GOMES, JA., 1996. Dynamics of energy and nutrient concentration and construction cost in a native and two alien C4 grasses from two neotropical savannas. Plant and Soil, vol. 181 , no. 2 , p. 175-184

CHATTERTON, NJ., HARRISON, PA., BENNETT, JH. and ASAY, KH., 1989. Carbohydrate partitioning in 185 accessions of Gramineae grown under warm and cool temperatures. Journal of Plant Physiology, vol. 134, no. 2, p. 169-179.

D'ANTONIO, CM. and VITOUSEK, PM., 1992. Biological invasions by exotic grasses, the grass/fire cycle, and global change. Annual Review of Ecology and Systematics, vol. 23, p. 63-87.

DUBOIS, M., GILlES, A., HAMILTON, JK., REBERS, PA. and SMITH, F., 1956. Colorimetric method for determination of sugars and related substances. Analytical Chemistry, vol. 28, no. 3 , p. $350-355$. 
FILGUEIRAS, TS., 1990. Africanas do Brasil: gramíneas introduzidas da África. Caderno de Geociências, vol. 5, no. 5, p. $57-63$

FILGUEIRAS, TS., 2002. Herbaceous plant communities. In OLIVEIRA, PS. and MARQUIS, RJ. (Eds.). The Cerrados of Brazil: ecology and natural history of a neotropical savanna. New York: Columbia University Press. p. 131-139.

HOFFMANN, WA., LUCATELLI, VMPC., SILVA, FJ., AZEVEDO, INC., MARINHO, MS., ALBUQUERQUE, AMS., LOPES, AO. and MOREIRA, SP., 2004. Impact of the invasive alien grass Melinis minutiflora at the savanna-forest ecotone in the Brazilian Cerrado. Diversity and Distribution, vol. 10, no. 2, p. 99-103.

HUMPHREY, LD. and SCHUPP, EW., 2004. Competition as a barrier to establishment of a native perennial grass (Elymus elymoides) in alien annual grass (Bromus tectorum) communities. Journal of Arid Environments, vol. 58, no. 4, p. 405-422.

KINGSTON-SMITH, AH., GALTIER, N., POLLOCK, CJ. and FOYER, CH., 1998. Soluble acid invertase activity in leaves is independent of species differences in leaf carbohydrates, diurnal sugar profiles and paths of phloem loading. New Phytologist, vol. 139 , no. 2, p. 283-292.

KLINK, CA. and JOLY, CA., 1989. Identification and distribution of $\mathrm{C} 3$ and $\mathrm{C} 4$ grasses in open and shaded habitats in São Paulo State, Brazil. Biotropica, vol. 21, no. 1, p. 30-34.

KLINK, CA. 1996. Germination and seedling establishment of two native and one invading African grass species in the Brazilian cerrado. Journal of Tropical Ecology, vol. 12, n. 1, p.139-147.

LEISHMAN, MR., HASLEHURST, T., ARES, A. and BARUCH, Z., 2007. Leaf trait relationships of native and invasive plants: community- and global-scale comparisons. New Phytologist, vol. 176, no. 3, p. 635-643.

LIU, X. and HUANG, B., 2000. Carbohydrate accumulation in relation to heat stress tolerance in two creeping bentgrass cultivars. Journal of the American Society of Horticultural Science, vol. 125, no. 4, p. 442-447.

MCCUNE, B. and MEFFORD, MJ., 1997. PC-ORD: multivariate analysis of ecological data. Version 3.0. Oregon: MjM Software Design.

MORAES, MG., SOUZA, A., PESSONI, RAB. and FIGUEIREDO-RIBEIRO, RCL., 2002. Soluble carbohydrate similarities between Echinolaena inflexa and Melinis minutiflora (Poaceae). Hoehnea, vol. 29, p. 151-158.

OLSON, BE. and WALLANDER, RT., 1997. Biomass and carbohydrate of spotted knapweed and Idaho fescue after repeated grazing. Journal of Range Management, vol. 50, no. 4, p. $409-412$.
PIVELLO, VR., CARVALHO, VMC., LOPES, PF., PECCININI, AA. and ROSSO, S., 1999a. Abundance and distribution of native and alien grasses in a "cerrado" (Brazilian savanna) Biological Reserve. Biotropica, vol. 31, no. 1, p. 71-82.

PIVELLO, VR., SHIDA, CN. and MEIRELLES, ST., 1999b. Alien grasses in Brazilian savannas: a threat to the biodiversity. Biodiversity and Conservation, vol. 8, no. 9, p. 1281-1294.

POLLOCK, CJ. and JONES, T., 1979. Seasonal patterns of fructan metabolism in forage grasses. New Phytologist, vol. 83, no. 1 , p. 9-15.

RIBEIRO, RV., LYRA, GB., SANTIAGO, AV., PEREIRA, AR., MACHADO, EC. and OLIVEIRA, RF., 2006. Diurnal and seasonal patterns of leaf gas exchange in bahiagrass (Paspalum notatum Flügge) growing in a subtropical climate. Grass and Forage Science, vol. 61, no. 3, p. 293-303.

ROSAS, HL., MORENO-CASSOLA, P. and MENDELSSOHN, IA., 2006. Effects of experimental disturbances on a tropical freshwater marsh invaded by the African grass Echinochloa pyramidalis. Wetlands, vol. 26, no. 2, p. 593-604.

SHEWMAKER, GE., MAYLAND, HF., ROBERTS, CA., HARRISON, PA., CHATTERTON, JN. and SLEPER, DA., 2006. Daily carbohydrate accumulation in eight tall fescue cultivars. Grass and Forage Science, vol. 61, no. 4, p. 413-421.

SIMOES, M. and BARUCH, Z., 1991. Responses to simulated herbivory and water stress in two tropical C4 grasses. Oecologia, vol. 88 , no. 2 , p. $173-180$

SOUZA, A., SANDRIN, CZ., MORAES, MG. and FIGUEIREDO-RIBEIRO, RCL., 2005. Diurnal variations of non-structural carbohydrates in vegetative tissues of Echinolaena inflexa, Melinis minutiflora and Lolium multiflorum (Poaceae). Revista Brasileira de Botânica, vol. 28, no. 4, p. 755-763.

VÁGÚJFALVI, A., KEREPESI, I., GALIBA, G., TISCHNER, T. and SUTKA, J., 1999. Frost hardiness depending on carbohydrate changes during cold acclimation in wheat. Plant Science, vol. 144, no. 2, p. 85-92.

VITOUSEK, PM., 1990. Biological invasions and ecosystem processes: towards an integration of population biology and ecosystem studies. Oikos, vol. 57, no. 1, p. 7-13.

WILLIAMS, DG. and BARUCH, Z., 2000. African Grass Invasion in the Americas: ecosystem consequences and the role of ecophysiology. Biological Invasions, vol. 2, no. 2, p. 1573-1464.

YOSHIDA, M., ABE, J., MORIYAMA, M. and KUWABARA, T., 1998. Carbohydrate levels among winter wheat cultivars varying in freezing tolerance and snow mold resistance during autumn and winter. Physiologia Plantarum, vol. 103, no. 1, p. 8-16. 